Covered in: ERIH PLUS, CEEOL, Index Copernicus, CrossRef, CrossCheck, J-Gate, Google Scholar, Ideas RePeC, Econpapers, Socionet, KVK, WorldCat.

Review on Repere ale autobiografiei spirituale din spaţiul ortodox în secolele XIX şi XX - Ioan de Kronstadt, Siluan Athonitul şi Nicolae Berdiaev, authored by Iuliu-Marius Morariu

\section{Antonio SANDU1}

${ }^{1}$ Professor PhD Hab, Stefan cel Mare University of Suceava, Romania, antonio1907@yahoo.com
Abstract: The volume Highlights of the spiritual autobiography in the orthodox space in the 19th and 20th centuries - John of Kronstadt, Silouan the Athonite and Nikolai Berdyaev - (Repere ale autobiografiei spirituale din spaţiul ortodox în secolele XIX şi XX - Ioan de Kronstadt, Siluan Athonitul şi Nicolae Berdiaev -), of the author IuliuMarius Morariu, published at LUMEN Publishing House, presents a theological - metaphysical and stylistic analysis of autobiographical writings of three Christian thinkers and spiritual experiencers of whom at least two have attained holiness.

Keywords: Iuliu-Marius Morariu; spirituality; orthodox area; spiritual autobiography; John of Kronstadt; Silouan the Athonite; Nikolai Berdyaev.

How to cite: Sandu, A. (2019). Review on Repere ale autobiografiei spirituale din spațiul ortodox în secolele XIX şi XX - Ioan de Kronstadt, Siluan Athonitul şi Nicolae Berdiaev, authored by Iuliu-Marius Morariu. Logos Universality Mentality Education Novelty: Philosophy \& Humanistic Sciences, 7(2), 78-83. doi: 10.18662/lumenphs/29 
Review on Repere ale autobiografiei spirituale din spațiul ortodox în secolele ... Antonio SANDU

\section{Introduction}

Spiritual autobiography is a gender of theological and philosophical writing rarely encountered in the Eastern Christianity area. Among many other reasons, one of the most important is the spirit of humility which, in the Orthodox tradition, keeps away the experiencer of life in God from anything that might be considered self-praise.

However, the ascetic labors of the toilers into God can be of great spiritual benefit to those who will need them in their future hardships, as a living instance to them that what they are experiencing - the sweetness of God's sight but, before this, the trials through which the Christian mystic passes - were not given only to them for testing, but they were also experienced by disciples and also by spiritualized beings who have ascended, before them, the ladder of divine ascent.

The volume Highlights of the spiritual autobiography in the orthodox space in the 19th and 20th centuries - John of Kronstadt, Silouan the Athonite and Nikolai Berdyaev - Repere ale autobiografiei spirituale din spatiul ortodox in secolele XIX si XX - Ioan de Kronstadt, Siluan Athonitul si Nicolae Berdiaev -), of the author Iuliu-Marius Morariu, published at Lumen Publishing House, presents a theological - metaphysical and stylistic analysis of autobiographical writings of three Christian thinkers and spiritual experiencers of whom at least two have attained holiness.

\section{Philosophical and anthropological perspectives on the Eastern mysticism}

The perspective that this book opens can be important for the Romanian theological thinking, however we will not refer to it in this review, having neither the call nor the quality to do it and not saying anything in addition to the words of H.E. Andrei, Metropolitan of Cluj, Maramureș and Sălaj: "We say with conviction that father Maxim Morariu's work is a pioneering one, based on research and documentation of great scientific and documentary, theological competence, which is why we congratulate him for and we hope that his work will be useful to the readers."

What will interest us in this review is related to the philosophical perspective opened on the Orthodoxy of the 19th and the 20th centuries, namely the focus on living in Christ experienced as sanctification and lived as a sanctifying prayer. As it results from the self-confessions of the three Christian thinkers/experiencers, living in Christ is deifying and deification is the ultimate goal of the Orthodox way of living, as a state of holiness, by 
sanctifying every moment of our life. The consciousness of being exceptional can make a person living in Christ narrate his ascetic labors not for vainglory, as other authors of the autobiographical literature in the secular world may be tempted to do, but to awaken humility and longing for God in those who observe in the texts they read that deification can be a current state, experienced here and now, not just a promised condition in a prospective paradise.

Orthodoxy is thus revealed as a thought of the Divinity incarnated by the Son and confessed by Christ in every living being in whom God is made alive.

We will also be interested, in reading the volume, by the anthropological perspective, opened to a society whose Saints and highly spiritual living beings reveal themselves as models that not only can be followed but who assume, in fact, the role of coagulating the Christian living towards the experiential spiritual life and not just towards the theological speech of scholastic kind.

The author of the volume Highlights of the spiritual autobiography in the orthodox space in the 19th and 20th centuries - John of Kronstadt, Silouan the Athonite and Nikolai Berdyaev - (Repere ale autobiografiei spirituale din spatiul ortodox in secolele XIX și XX - Ioan de Kronstadt, Siluan Athonitul și Nicolae Berdiaev -), Iuliu-Marius Morariu draws attention to the fact that the autobiographical perspective in the Christian writings originates from the Pauline writings. The Pauline and later the Augustinian autobiographical approach constitute benchmarks for the establishment of a mystical literature based on autobiography, which is but little represented in the Eastern space, being more present in the Western theological thinking. Such autobiographical accounts, however, are not missing, though they are episodic, from the works of theologians and saints such as St. John Chrysostom, Gregory of Nazianzus and Gregory of Nyssa.

By presenting these models of spiritual autobiography, along with other models of autobiographical writings belonging to the Catholic tradition, such as Saint Teresa of Avila, describing the mystical experiences of ecstatic kind and their role in the spiritual transformation of a Christian, Iulius Marius Morariu prepares his analysis on to the three Orthodox theologians John of Kronstadt, Silouan the Athonite and Nikolai Berdyaev.

The autobiography of St. John of Kronstadt, as presented by the author of this volume, is a confession of the humility that has accompanied him throughout his life and his spiritual development. From the philosophical perspective from which we set out to approach this review, the idea of intimacy with God appears as significant for the autobiography 
Review on Repere ale autobiografiei spirituale din spațiul ortodox în secolele ... Antonio SANDU

of John of Kronstadt as for the other autobiographies. The narration is about the man who is sanctified, but behind it the story is about God who is always making Himself present to the man. The intimacy with God is of mystical type, not a meeting with a distant, omnipotent otherness, but with a spiritual Friend, who accompanies the Saint at the same time from the boundlessness of His almightiness but also from the continuous presence of the Grace given to the Saint in response to his spiritual search and also as an expression of God's faultless will.

In this volume it is shown that, although the mentions regarding the ecstatic experiences of Saint John of Kronstadt are rare, they are not missing, the saint speaking out about the "mystical union with the Divinity" (Morariu, 2019, p. 227) and how it should be understood: "As in seas, lakes or rivers, each particle of water finds itself in combination with other particles and it is surrounded by those ones, the same for us, sons of earth, we are surrounded on all sides by God, and the purest of us, they are about to be cleansed, they are in union with Him, being everywhere in Him. All of us, earthlings, are just like water, like air, like a branchy tree, making up a whole, but sometimes dismembered, because of the envy of the devil, of selfishness, of annoyance, of enmity, of dishonesty, of pride, of heresies and divisions, of malice, of isolationism, of wickedness, of witchcraft and so many other passions "(St. John of Kronstadt, 2005).

Without being a form of pantheism, as it appears in some Eastern religions, the idea of the omnipresence of God is symbolically transposed as existential nearness of man and God. The existential nearness becomes intimacy when the human being re-encounters ("knows") God. Although God is everywhere, so also in man, the latter can recognize him only when man, seeking God, receives His grace.

From an anthropological point of view, such a theology will be the basis of a culture of inner greatness due to the existential proximity to the Divine and compensated by a humility towards the outer world emptied of meaning in the absence of perceiving the divine presence in the world. The world is a place of grief there where God cannot find his place.

A second spiritual autobiographical perspective presented by Iulius Marius Morariu in the volume Highlights of the spiritual autobiography in the Orthodox space during the 19th and 20th centuries - John of Kronstadt, Silouan the Athonite and Nikolai Berdyaev - is that of Saint Silouan the Athonite, also of Russian origin, like John of Kronstadt. His autobiography was subsumed to the thought planted in his mind by the Savior Jesus Christ himself, who revealed Himself to him after a period of spiritual search and ascetic labors : "Keep your mind in hell and despair not" (Sakharov, 2013). 
The anthropological perspective opened by this new "commandment" is that of the hope that accompanies humility. The search for the ceaseless prayer, as it appears in the confessions of Saint Silouan the Athonite, is rather an inner one, the isibia (the silence of mind) overlapping with finding out the value of the mystery of obedience. In the Saint's situation, the love for God continues with the love for the entire creation.

The search for grace is of overwhelming importance in the spiritual autobiography of Saint Silouan the Athonite. He shows that the fullness of God's grace is almost impossible to maintain for an ordinary human being who is unfamiliar with obedience and spiritual endeavors.

Here, a metaphysical perspective specific to Orthodoxy is being opened, otherwise a perspective of patristic tradition, which is related to the growth in grace, the deification (theosis) being the work of the Grace that begins to inhabit the ascetic. In fact, the continuous prayer is that of the Grace in the heart, that transforms the human being into the image of God. We see here a metaphysics of transubstantiation, where the natural proves to be supernatural, when inhabited by the Grace of God.

The third Christian thinker and experiencing spiritual life, who caught the attention of Iulius Marius Morariu, is Nikolai Berdyaev, also of Russian origin. Berdyaev's philosophy questions the specificity of Christian thinking, which is divided by the fear of the divine exigency, on one hand and mystically justified by the real and visible transfiguration of man within the endless love of God. (Berdyaev, 2009, p. 59).

Berdyaev shows that God needs the man as a part of Himself (Berdiaev, 2009, p. 94). By the incarnation of Christ, God assumes the human nature and this nature becomes part of the Godhead. Through mystical love, humanity assumes the divine nature that becomes part of it. Berdyaev's anthropology paves the way for a Christocentric anthropocentrism.

\section{Instead of conclusions}

The volume Highlights of the spiritual autobiography in the orthodox space in the 19th and 20th centuries - John of Kronstadt, Silouan the Athonite and Nikolai Berdyaev - Repere ale autobiografiei spirituale din spatiul ortodox in secolele XIX si XX - Ioan de Kronstadt, Siluan Athonitul si Nicolae Berdiaev -), of the author Iuliu-Marius Morariu, published at Lumen Publishing House, can be the ground for some philosophical investigations as well as for some Christian anthropology investigations on the Orthodox mysticism of the modern period. An anthropology of holiness could be continued in the same 
Review on Repere ale autobiografiei spirituale din spațiul ortodox în secolele ... Antonio SANDU

tradition opened by St. John of Kronstadt and St. Silouan the Athonite, with the writings of the main disciple of St. Silouan the Athonite, Saint (recently canonized) Sophrony Sakharov, of Essex, and maybe, in the future, from the Romanian space, by Fr. Rafail Noica.

Acknowledgement: book review translated by Bianca Sandu

\section{References}

Morariu, I. M. (2019). Repere ale autobiografiei spirituale din spatiul ortodox in secolele XIX si XX - Ioan de Kronstadt, Siluan Athonitul si Nicolae Berdiaev-. [ Highlights of the spiritual autobiography in the orthodox space in the 19th and 20th centuries - John of Kronstadt, Silouan the Athonite and Nikolai Berdyaev - ]. Iaşi, România: LUMEN.

Sfântul Ioan de Kronstadt (2005). Viaţa mea în Hristos. [My life in Christ]. Bucureşti, România: Sophia.

Sakharov, S. (2013). Cuviosul Siluan Athonitul. [Saint Silouan the Athonite]. Suceava, România: Accent Print.

Berdiaev, N. (2009). Pour un christianisme de création et de liberté. Paris, France: Les Editions du Cerf. 